\title{
Protests and promises grow in Russia as science spending falls
}

[MOscow] Russia's finance minister, Alexander Lifshits, promised scientists last week that he would speed up payment of the science budget, and expressed optimism that - unlike last year - it will be paid in full.

The promise followed growing discontent over the late payment of salaries, as well as the poor state of the science budget. President Boris Yeltsin has signed into law Russia's budget for 1997, already approved by both chambers of the Russian parliament, allocating 15,258 billion rubles (US $\$ 2.6$ billion) to research and development (R\&D). Of this figure, 5,731 billion rubles will be spent on fundamental research and 9,526 billion rubles on the development of new technologies.

But the planned spending on R\&D represents only 2.7 per cent of all budget expenditure - considerably less that the 4 per cent mandated in a law passed last August. Furthermore, there is growing concern among scientists that more than half this sum will make its way back to the government through taxation.

Proposed changes to the tax laws drawn up by the finance ministry would, if adopted, deprive scientists of privileges which are currently worth 8,000 billion rubles. Scientific organizations would be required to pay both value added tax and local land taxes, while all recipients of research grants would have to pay income tax on the money they receive.

"Under these conditions, foreign organizations which support Russian science are likely to decide not to finance the bureaucracy, and thus to stop giving grants to Russian scientists," says Alexander Spirin, a member of the Russian Academy of Sciences.

Vladimir Kudryavtsev, a vice president of the academy and former director of its Institute of the State and Law, complains that the "new tax code had been prepared without consulting the scientific community, in strict secrecy, and in spite of the fact that the academy itself possesses hundreds of highly qualified specialist in its economics department."

The difficulties facing scientists are compounded by the fact that not all the money allocated to them actually arrives, while the distribution of funds between different fields of science is very uneven. Last year, for example, the Russian Space Agency received 97.3 per cent of what had been planned, a reflection of US pressure on Russia over its planned participation in the international space station; in contrast, the Russian Foundation for Fundamental Research received only 37 per cent.

With many scientists receiving their salaries at least a month late, a series of protest meetings has been held. These began in the academy's biological scientific centre at Pushchino near Moscow, where 3,000 of the 20,000 staff have demanded the resignation of the government and retirement of the president.

Such demands have been supported by scientists in St Petersburg, Vladivostok and Moscow, where about 300 people picketed the White House, the main parliament building. Their representatives were met by Lifshits and Vladimir Fortov, chairman of the State Committee on Science and Technologies.

On behalf of the cabinet, Lifshits signed a promise that scientists will in future receive the same priority on salaries as teachers and service personnel. A schedule of monthly payments of the science budget was also approved: this month, scientists are to receive 950 billion rubles, and a further 750 billion rubles will be paid in each of the following three months - equivalent to a quarter of the annual budget.

A further meeting between members of the cabinet and representatives of the scientific community will be held in June to discuss plans for the second half of the year. Lifshits promised to find additional finance for science, in particular using foreign loans. He also expressed optimism that the remaining three-quarters of the science budget would be paid by the end of the year.

Meanwhile, Yeltsin has appointed Yuri Osipov, the president of the academy who was recently appointed to the cabinet, as a member of the Security Council. Another academy member, Boris Berezovsky, was recently made deputy chairman of the council. The 1,200 academy members are waiting to see whether the appointments will have any impact on their plight. Carl Levitin

\section{Lab director exits bloody but unbowed}

[WASHINGTON] Few modern research administrators have managed to personify their institution in quite the way that Nick Samios has come to represent the Brookhaven National Laboratory in New York state since his appointment as director there in 1982.

Then, Brookhaven had just been forced to abandon work on a giant particle accelerator called Isabelle, which had been intended to ensure the laboratory's future as a centre for particle physics research. Now, the Long Island laboratory is home to the National Synchrotron Light Source, a vastly popular source of X-ray, ultraviolet and infrared radiation.

Many smaller projects and centres have broadened the laboratory's scientific base. And the completion in 1999 of a brand new nuclear physics facility, the Relativistic Heavy Ion Collider, should assure Brookhaven a sparkling future.

Or so it appeared until the discovery in January of an underground plume of radioactive tritium emanating from Brookhaven's other large user facility, the
High-Flux Beam Reactor (see Nature 386, 3; 1997). The furore over the leak - which, as Samios ruefully observes, amounts to around 30 cubic millimetres of the hydrogen isotope - overshadowed the announcement on 7 March that he will quit as Brookhaven's director.

Tears were shed at the laboratory that morning, according to Brookhaven staff. They were probably provoked not by concern for Samios, who is well able to look after himself, but by exasperation inside the besieged laboratory as activists and local politicians - notably Senator Alfonse D'Amato (New York, Republican) — sought to blame Samios for the leak and take credit for his departure. "D'Amato will say anything he thinks will get him re-elected," observes one prominent physicist unconnected with Brookhaven.

Samios denies that he was forced out, saying that he had notified Associated Universities Inc., the contractor that runs Brookhaven, a year ago that he was intending to leave after 15 years in the job. Sources outside the laboratory confirm this. But they 